\title{
Chemotaxonomic Characters and Classification of Some Nocardioform Bacteria
}

\author{
By HALINA MORDARSKA AND M. MORDARSKI \\ Department of Biosynthesis, Institute of Immunology and Experimental Therapy, \\ Polish Academy of Sciences, Wroclaw, Poland \\ AND M. GOODFELLOW \\ Department of Microbiology, The Medical School, University of Newcastle, \\ Newcastle upon Tyne, $N E \mathrm{I} 7 R U$
}

(Accepted for publication 6 January 1972)

\begin{abstract}
SUMMARY
Simple chemical analyses were carried out on $\mathrm{I} 98$ nocardioform bacteria by means of paper- and thin-layer chromatography. The strains considered to belong to the genus Nocardia contained the lipid LCN-A, arabinose and meso-diaminopimelic acid. All the representative strains from the 'Mycobacterium' rhodochrous complex possessed this lipid though in certain cases the characteristic spot had a slightly lower $R_{F}$ value than that of the reference lipid LCN-A from the standard strain of Nocardia asteroides. The genera Actinomadura, Mycobacterium, Oerskovia and Streptomyces did not contain lipid LCN-A and the distribution of the other two chemical characters varied. The method used to detect lipid LCN-A is simple and reliable and permits the separation of nocardias and ' $M$.' rhodochrous strains from allied taxa. These results correlate well with other trends in the taxonomy of nocardioform bacteria and confirm the value of chemotaxonomic characters, especially lipids, in the classification and identification of these organisms.
\end{abstract}

\section{INTRODUCTION}

The term nocardioform was coined by Prauser (1967) to refer to bacteria able to produce a primary mycelium which by regular division gives rise to cocci and rod-shaped elements. The taxonomy of these bacteria is still difficult but, as the results of modern studies accumulate, an outline of some of the major groups is emerging. Groups of nocardioform strains proposed on the basis of wall composition and whole organism hydrolysate analyses (Becker, Lechevalier \& Lechevalier, 1965; Lechavalier \& Lechevalier, 1970a) have been recovered as major clusters in an extensive numerical taxonomic study (Goodfellow, I97I). The chemotaxonomic and phenetic evidence has unequivocally shown that the genus Nocardia as characterized in Bergey's Manual (Waksman, 1957) is heterogeneous and these data support the case for the acceptance of the newly proposed genera Actinomadura (Lechevalier \& Lechevalier, 1970 b) and Oerskovia (Prauser, Lechevalier \& Lechevalier, 1970). The erection of these taxa leaves the genus Nocardia as a homogeneous group containing the major species Nocardia asteroides, $N$. brasiliensis and $N$. caviae.

It is not possible, at present, to separate nocardias sensu novo, mycobacteria and certain corynebacteria by wall composition characters. The strains in these three genera all have walls of Type IV (Becker et al. 1965). Simple but reliable tests for the differentiation of these taxa are required. Additional chemical data may be useful because some chemotaxonomic characters have been shown to be stable under various environmental conditions and even 
appear to be unaffected by the age of the culture or by mutagens (Šuput, Lechevalier \& Lechevalier, 1967).

Preliminary studies suggest that lipid composition may be useful in the classification of actinomycetes (Lanéelle, Asselineau \& Castelnuovo, 1965; Etémadi, 1967a, $b$ ). In an extensive study using pyrolysis gas chromatography, Lechevalier, Horan \& Lechevalier (I97I) distinguished between Mycobacterium, Nocardia and Corynebacterium by the kind of mycolic acids they possessed. Previous to this Mordarska (I968) and Mordarska \& Mordarski (I969) had found a lipid which seemed to be specific for nocardias. This lipid was subsequently called Lipid Characteristic of Nocardia or LCN-A (Mordarska \& Réthy, 1970). We are reporting here an extension of these studies in which a comprehensive collection of nocardia strains and representatives of the genera Actinomadura, Mycobacterium, Oerskovia, Streptomyces and the 'Mycobacterium' rhodochrous complex were examined for the presence of lipid LCN-A, arabinose and diaminopimelic acid (DAP). Sufficient strains were studied for significant conclusions to be drawn on the taxonomic importance of lipid LCN-A.

\section{METHODS}

Organisms and growth conditions. The name, number and concise history of the 198 strains tested are listed in Tables I and 2. Many of these organisms were included in the numerical study of Goodfellow (I97I) where comprehensive strain histories can be found. All the cultures were grown in shake flasks at $37^{\circ} \mathrm{C}$ for 3 to 5 days in glucose peptone broth (Prauser $\&$ Falta, 1968) and in modified Sauton's medium (Mordarska, 1968). The latter contained (g/l distilled water): glucose, I5.0; asparagine, 5.0; casein hydrolysate, 2.0; sodium citrate, $\mathrm{I} \cdot 5 \mathrm{~g} ; \mathrm{KH}_{2} \mathrm{PO}_{4}, 5.0 ; \mathrm{MgSO}_{4} .7 \mathrm{H}_{2} \mathrm{O}, 0.5 ; \mathrm{K}_{2} \mathrm{SO}_{4}, 0.5 ;$ and ferric ammonium citrate, a trace; $\mathrm{pH} 7 \cdot 2$. The glucose was sterilized separately.

Preparation of lipid extracts. Cultures were checked for purity at maximal growth, killed by shaking with I $\%(v / v)$ formalin, harvested by filtration and thoroughly washed with water. Two $\mathrm{ml}$ of an ethanol-diethyl ether mixture ( $\mathrm{I}: \mathrm{I}$ ) was added to $100 \mathrm{mg}$ of dried crushed organism. The centrifuge tubes were sealed with Parafilm (American Can Co., Wisconsin), and left $\mathrm{x}$ : room temperature for 3 to $4 \mathrm{~h}$. For a good extraction the tubes were occasionally shaken and the solvent mixtures changed twice. The supernatant obtained after centrifugation was evaporated to dryness at $35 \mathrm{C}^{\circ}$ and the residue stored at $4{ }^{\circ} \mathrm{C}$ until use. Lipid extracts from Nocardia asteroides USA, $N$. calcarea IMET $70 \mathrm{I} 8$ and Streptomyces griseus 22, which had been examined in previous studies (Mordarska, I968; Mordarska \& Mordarski, 1970) were used as standard references.

Chromatography. Glass plates $20 \times 20 \mathrm{~cm}$ were covered with a $0.5 \mathrm{~mm}$ layer of silica gel $\mathrm{G}$ (E. Merck Ag, Darmstadt, W. Germany) and activated for $2 \mathrm{~h}$ at $110^{\circ} \mathrm{C}$. The lipid residue was dissolved in a 0.05 to $0.1 \mathrm{ml}$ mixture of chloroform and methyl alcohol (3:I), and 25 to $50 \mu \mathrm{l}$ of this extract used for the analysis. Chromatograms were developed in the solvent system petroleum ether (b.p. 45 to $66^{\circ} \mathrm{C}$ )-diethyl ether-glacial acetic acid (85:15:1). Similar separations were obtained in the solvent systems $n$-hexane-diethyl ether-glacial acetic acid $(70: 30: 2)$ and petroleum ether (b.p. 40 to $60^{\circ} \mathrm{C}$ )-diethyl ether-glacial acetic acid (90:I0:I). If lower b.p. petroleum ether is used and when the LCN-A spot is difficult to interpret, it is advisable to dry the plates and re-run them in pure methanol. In methanol most of the lipids, but not lipid LCN-A, moved with the solvent front. After the chromatograms had been developed the plates were dried for 3 to $4 \mathrm{~h}$ at 35 to $45^{\circ} \mathrm{C}$ and then exposed to iodine vapour. The lipid spots appeared after about $5 \mathrm{~min}$. All analyses were made in duplicate or in triplicate.

Arabinose and diaminopimelic acid. Acid hydrolysates of the mycelium were examined for arabinose and diaminopimelic acid by paper chromatography by means of the techniques 

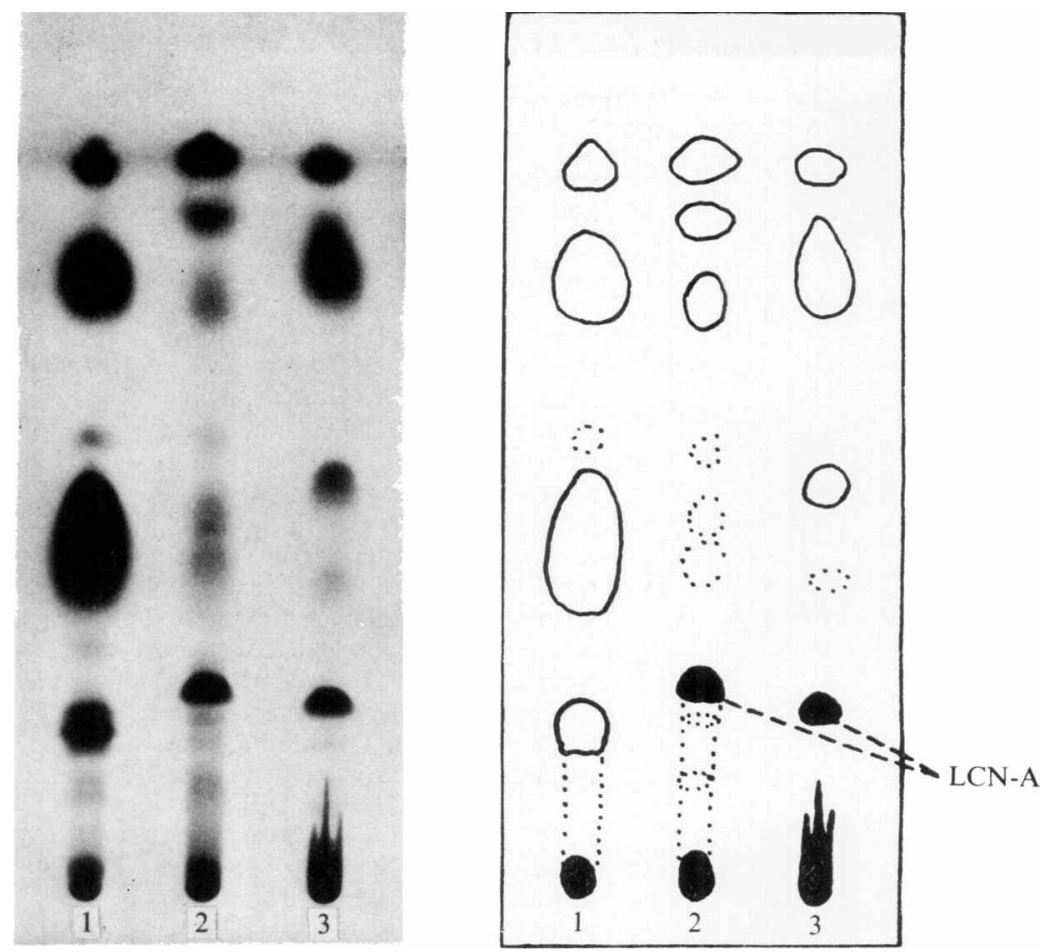

Fig. I. Thin-layer chromatogram of cell lipids of the standard strains: I, Streptomyces griseus 22; 2, Nocardia asteroides USA; $3, N$. calcarea IMET 70 I 8 . Solvent system: petroleum ether-diethyl ether-glacial acetic acid $(85: 15: 1)$.

described by Murray \& Proctor (1965) and Becker, Lechevalier, Gordon \& Lechevalier (I964). Undefatted cells as well as those remaining after lipid extraction were used in these experiments.

\section{RESULTS}

The cells of the 143 cultures listed in Table I contained lipid LCN-A, arabinose and mesodiaminopimelic acid. Some of the strains gave an LCN-A spot which had a slightly lower $R_{F}$ value than that of the standard Nocardia asteroides USA strain. The position of this analogue in chromatograms corresponded with the LCN-A spot of the standard $N$. calcarea IMET 7OI 7 (Fig. I). This analogue, lipid LCN-A 'calcarea' was found in N. calcarea and in some of the strains of the 'Mycobacterium' rhodochrous complex. The remaining strains contained the normal lipid LCN-A 'asteroides' type.

The 55 cultures which did not contain lipid LCN-A are shown in Table 2. None of these cultures can be accommodated in the genus Nocardia sensu novo but belong either to the new genera Actinomadura and Oerskovia or to the established taxa Mycobacterium and Streptomyces. The other chemical data indicated that the streptomycetes had a wall Type I, and the actinomaduras a wall Type III (Lechevalier \& Lechevalier, I970a).

Twenty strains received as Nocardia spp. did not contain lipid LCN-A. Six of these organisms had a wall Type I, ten a wall Type III, and the remaining four possessed a wall Type IV. Identical results were obtained with defatted and undefatted cells. 
Table I. Strains containing lipid $L C N-A$, arabinose and meso-diaminopimelic acid

Name of strain

Nocardia asteroides

N. brasiliensis
Strain no.

NI3

N70

$\mathrm{N} 76$

N77

N96

N97

N98

NIOO

NIO6

NI 19

NI 2 I

$\mathrm{NI} 27$

N2O4

N2I 6

N3I 7

N364

N366

$\mathrm{N} 458$

$\mathrm{N} 483$

N486

N489

$\mathrm{N} 492$

N509

N5I 2

N5I 8

N519

N520

N528

N48

NI 18

N3I 8

N367

N368

N425

N426

N427

$\mathrm{N} 428$

N429

N438

N439

N464

N465

N466

N467

N468

N469

$\mathrm{N} 47 \mathrm{O}$

N47I

N474

N475

$\mathrm{N} 476$

N48I
Source

NCTC 8595

IAM 0374

S. T. Williams, Liverpool University, EI3

S. T. Williams, EI5

R. E. Gordon, Rutgers University, New Brunswick, U.S.A., w3300

R. E. Gordon, N659

R. E. Gordon, 618

R. E. Gordon, 652

R. E. Gordon, A9504

CBS 255. 58

CBS 333. 5 I

CBS 248. 33

ATCC 7372

J. E. Thiemann, Lepetit, Milan, s547 ATCC 19247. Suggested working type (Sneath \& Skerman, 1966)

M. Tsukamura, The National Sanitorium, Aichi-ken 474, Japan, R399

M. Tsukamura, ATCC 9970

L. Ajello, Center for Disease Control, Atlanta, Georgia, U.S.A., $45-765-70$

L. Ajello, 45-995-70

L. Ajello, 45-1005-70

L. Ajello, 45-1007-70

L. Ajello, 45-1065-70

L. Ajello, 45-I I09-70

L. Ajello, 45-54-7I

L. Ajello, 45-23I-7I

L. Ajello, 45-246-71

L. Ajello, 45-274-71

L. Ajello, 45-379-7I

R. E. Gordon, 744

CBS 438. 64

ATCC 19296, uncertain cotype (Sneath \&

Skerman, I966)

M. Tsukamura, R432

M. Tsukamura, $R 887$

R. E. Gordon, 605

R. E. Gordon, 774A

R. E. Gordon, 774B

R. E. Gordon, 1336

R. E. Gordon, 73I

R. E. Gordon, 1 I08

R. E. Gordon, 3488

Institut Pasteur, Paris, 700

IP 70I

IP 704

IP 708

IP 723

IP 748

A. Gonzáles Ochoa, Instituto de Salubridad, Mexico 17,4060

A. Gonzáles Ochoa, 4I 15

A. Gonzáles Ochoa, 4212

A. Gonzáles Ochoa, 4023

A. Gonzáles Ochoa, 4025

J. A. Serrano, Universidad De Los Andes, Merida, 1548 
Table I (cont.)

Name of strain

$N$. brasiliensis

N. calcarea

N. caviae

$N$. congolensis

N. convoluta

N. cuniculi

N. farcinica

N. gardneri

N. marina

$N$. narashinoensis

N. pasteuroides

$N$. pelletieri

N. petroleophila

$N$. pretoriana

N. rhodnii

N. sylvodorifera

N. uniformis

N. vaccinii

Nocardia sp.
Strain no.

Source
L. Ajello, 45-944-70

L. Ajello, 45-IOI 2-70

$\mathrm{NCIB} 8863$

CCM 197

NCTC 1934, cotype (Sneath \& Skerman, I966)

R. Olds, Cambridge University, CN749

R. Olds, CN75I

IP 75I

IP 77 I

M. Tsukamura, RI3I5

M. Tsukamura, RI3I6

M. Tsukamura, R4I6

R. E. Gordon, I 370

R. E. Gordon, 737

R. E. Gordon, 416

R. E. Gordon, I 355

R. E. Gordon, 1316

R. E. Gordon, 424

IP 3 I 8

IP 772

NCTC 5175

A. Gonzáles Ochoa, 98

J. Antheunisse, Wageningen, Holland, ATCC 4275

NCTC 1935

M. Tsukamura, MI 33

M. Tsukamura, M205

M. Tsukamura, MI75

N360

N29

IFO 3385

NI 45

N69

N94

N78

$\mathrm{N} 43$

$\mathrm{N} 237$

N2I 9

N220

N443

$\mathrm{N} 444$

$\mathrm{N} 446$

N2 17

N3

N33

N9I

N350

$\mathrm{N} 403$

$\mathrm{N} 478$

N52I

$\mathrm{N} 522$
M. Turner, Nottingham University, 36

IAMOI 3

A. Gonzáles Ochoa, 35

NCIB 9438

I. Uesaka, Kyoto University, Japan, 194

C. da Silva Lacaz, São Paulo University, Brazil

C. da Silva Lacaz

P. Hill, Edinburgh University, A/I

P. Hill, A/o

P. Hill, B/I

J. E. Thiemann, s546

NCIB 963 I

NCPPB 954, Holotype (Sneath \& Skerman, 1966)

H. Veldkamp, Groningen University, A86

T. Watson, Liverpool University, A32

H. Weyland, Institut für Meeresforschung,

Bremerhaven, 3 I

L. Ajello, 45-908-70

CBS C568

CBS 5085
S. T. Williams, E2 I 
Table I (cont.)

Name of strain

Mycobacterium rhodochrous
Strain no.

\begin{tabular}{|c|c|}
\hline N4 & $\mathrm{NCIB} 9664$ \\
\hline N5 & NCIB970I \\
\hline N7 & NCIB 10027 \\
\hline N22 & CCM 3245 \\
\hline N25 & CCM 279 \\
\hline N26 & CCM I98 \\
\hline N27 & $\operatorname{cCM} 278$ \\
\hline $\mathrm{N} 28$ & $\operatorname{CCM} 269$ \\
\hline N3O & R. E. Gordon, AI 2974 \\
\hline N3I & R. E. Gordon, w2I \\
\hline N55A & R. E. Gordon, 8I7 \\
\hline N55B & Mucoid variant of $55 \mathrm{~A}$ \\
\hline N56 & R. E. Gordon, 1256 \\
\hline N57 & R. E. Gordon, $1293 \mathrm{~S}$ \\
\hline N58A & R. E. Gordon, 1257 \\
\hline N58B & Dry variant of $58 \mathrm{~A}$ \\
\hline N59 & R. E. Gordon, I 240 \\
\hline N60 & R. E. Gordon, I 293R \\
\hline N6I & R. E. Gordon, w3408 \\
\hline N62 & R. E. Gordon, 768 \\
\hline N63 & R. E. Gordon, 463 \\
\hline N65 & R. E. Gordon, A7698 \\
\hline N66 & NCTC 8139 \\
\hline N67 & NCTC 10210 \\
\hline N73 & S. T. Williams, E40 \\
\hline N75 & LAI609 \\
\hline NI08 & R. E. Gordon, A4277 \\
\hline NIO9 & R. E. Gordon, 494 \\
\hline NIIO & R. E. Gordon, w3639 \\
\hline NII 2 & $\begin{array}{l}\text { V. B. D. Skerman, Queensland University, } \\
\text { Australia, I 2 I }\end{array}$ \\
\hline NII3 & V. B. D. Skerman, I 34 \\
\hline NI23 & $\operatorname{CBS} 334.5 \mathrm{I}$ \\
\hline NI46 & M. Turner, 39 \\
\hline N240 & NCTC 857 I \\
\hline N324 & ATCC I 5998 \\
\hline N325 & $\begin{array}{l}\text { G. Castelnuova, Instituto Superiore Di Sanita, } \\
\text { Rome, 906B }\end{array}$ \\
\hline N326 & G. Castelnuova, 107 \\
\hline N420 & A. Tacquet, Institut Pasteur, Lille, 906 \\
\hline $\mathrm{N} 422$ & A. Tacquet, 107 \\
\hline N424 & $\begin{array}{l}\text { J. Norris, Millstead Laboratory, } \\
\text { Sittingbourne, Kent, } 330\end{array}$ \\
\hline N447 & R. Bönicke, Forschungs nstitut Borstel, sN5108 \\
\hline N450 & R. Bönicke, SN5303 \\
\hline N45I & R. Bönicke, SN5302 \\
\hline
\end{tabular}

ATCC $=$ American Type Culture Collection, Rockville, Maryland, U.S.A.; CBS = Centraalbureau voor Schimmelcultures, Baarn, Netherlands; IAM = Institute of Applied Microbiology, University of Tokyo, Japan; IFO = Institute of Fermentation, Osaka, Japan; LA = Institut d'Hygiene, Lausanne, Switzerland; NCIB = National Collection of Industrial Bacteria, Aberdeen; NCPPB = National Collection of Plant Pathogenic Bacteria, Harpenden, Hertfordshire; NCTC = National Collection of Type Cultures, London. 
Table 2. Strains which do not contain lipid LCN-A but which may have arabinose and/or diaminopimelic acid

\begin{tabular}{|c|c|c|c|c|}
\hline Name of strain & Strain no. & Source & $\begin{array}{l}\text { Arab- } \\
\text { inose }\end{array}$ & DAP \\
\hline \multirow[t]{6}{*}{ Actinomadura dassonvillei } & $\mathrm{N} 238$ & NCTC IO489 & - & $+(\mathrm{DL}, \mathrm{LL})$ \\
\hline & $\mathrm{N} 287$ & NCTC IO488 & - & $+(\mathrm{DL})$ \\
\hline & N433 & R. E. Gordon, 7I4 & - & $+(\mathrm{DL})$ \\
\hline & $\mathrm{N} 435$ & R. E. Gordon, I 322 & - & $+(\mathrm{DL})$ \\
\hline & $\mathrm{N} 436$ & R. E. Gordon, I 289 & - & $+(\mathrm{DL})$ \\
\hline & N437 & R. E. Gordon, 575 & - & $+(\mathrm{DL})$ \\
\hline \multirow[t]{4}{*}{ A. madurae } & $\mathrm{NI} 7$ & NCTC 1070 & - & $+(\mathrm{DL})$ \\
\hline & N80 & S. T. Williams, E23 & - & $+(\mathrm{DL}, \mathrm{LL})$ \\
\hline & $\mathrm{N} 8 \mathrm{I}$ & S. T. Williams, E24 & - & $+(\mathrm{DL})$ \\
\hline & N374 & M. Tsukamura, Sal. I & - & $+(\mathrm{DL})$ \\
\hline \multirow[t]{8}{*}{ A. pelletieri } & Ni 8 & NCTC IOOOO & - & $+(\mathrm{DL}, \mathrm{LL})$ \\
\hline & N49 & R. E. Gordon, 513 & - & $+(\mathrm{DL}, \mathrm{LL})$ \\
\hline & N79 & S. T. Williams, E22 & - & $+(\mathrm{DL})$ \\
\hline & $\mathrm{N} 282$ & $\begin{array}{l}\text { I. G. Murray, London School Tropical } \\
\text { Medicine, I067 }\end{array}$ & - & $+(\mathrm{DL})$ \\
\hline & N298 & IP 726 & - & $+(\mathrm{DL})$ \\
\hline & $\mathrm{N} 46 \mathrm{I}$ & IP 390 & - & $+(\mathrm{DL})$ \\
\hline & N462 & IP 389 & - & $+(\mathrm{DL})$ \\
\hline & $\mathrm{N} 463$ & IP 388 & - & $+(\mathrm{DL})$ \\
\hline Mycobacterium abscessus & M29 & LA948 & + & $+(\mathrm{DL})$ \\
\hline M. chitae & M26 & NCTC 10495, paratype & + & $+(\mathrm{DL})$ \\
\hline M. fortuitum & N294 & ATCC $684 \mathrm{I}$ & + & $+(D L)$ \\
\hline M. giae & M38 & LA 82 & + & $+(\mathrm{DL})$ \\
\hline M. phlei & $\mathrm{N} 290$ & NCTC $815 I$ & + & $+(\mathrm{DL})$ \\
\hline M. salmoniphilum & M32 & LA 1263, type & + & $+(\mathrm{DL})$ \\
\hline Nocardia aerocolonigenes & $\mathrm{N} 538$ & NRRL B3298, type & \pm & $+(\mathrm{DL})$ \\
\hline N. alba shoen & $\mathrm{N} 235$ & I. Uesaka, I 3 & - & $+(\mathrm{LL})$ \\
\hline N. apis & N8 & $\mathrm{NCIB} 9378$ & - & $+(\mathrm{LL})$ \\
\hline N. capreola & N540 & NRRL 2773, type & \pm & $+(\mathrm{DL})$ \\
\hline N. cellulans & $\mathrm{N} 4 \mathrm{O}$ & NCIB 8868 & - & $+(\mathrm{DL})$ \\
\hline N. coeliaca & NI & NCIB9574 & + & $+(\mathrm{DL})$ \\
\hline \multirow[t]{2}{*}{ N. farcinica } & N34 & $\begin{array}{l}\text { NCTC } 4524 \text {, cotype (Sneath \& Skerman, } \\
\text { I966) }\end{array}$ & + & $+(\mathrm{DL})$ \\
\hline & NI2O & CBS 223. 60 & + & $+(\mathrm{DL})$ \\
\hline N. formica & $\mathrm{N} 203$ & ATCC I48 I I & - & $+(\mathrm{LL})$ \\
\hline N. gibsonii & $\mathrm{N} 205$ & ATCC 6852 & - & $+(L L)$ \\
\hline N. italica & N9 & NCIB9386 & - & $+(\mathrm{DL}, \mathrm{LL})$ \\
\hline N. lurida & $\mathrm{N} 53 \mathrm{I}$ & CBS 609.67 & - & $+(\mathrm{DL})$ \\
\hline $\begin{array}{l}\text { N. lurida } \\
\text { N. orientalis }\end{array}$ & $\mathrm{N} 2$ & NCIB960I & - & $+(\mathrm{DL})$ \\
\hline & N539 & NRRL 2540, type & \pm & $+(\mathrm{DL})$ \\
\hline & N207 & ATCC 15747 & - & $+(\mathrm{LL}$ trace $)$ \\
\hline $\begin{array}{l}N . \text { polychromogenes } \\
N . \text { rangoonensis }\end{array}$ & $\mathrm{N} 72$ & LA I6IO & - & $+(\mathrm{DL})$ \\
\hline $\begin{array}{l}N . \text { rangoonensis } \\
N . \text { rugosa }\end{array}$ & N206 & ATCC 6860 & - & $+(\mathrm{LL})$ \\
\hline & N44 & NCIB 8926 & + & $+(\mathrm{DL})$ \\
\hline $\begin{array}{l}\text { N. saturnea } \\
\text { N. tenuis }\end{array}$ & $\mathrm{N} 45$ & NCIB9437 & - & $+(\mathrm{DL}, \mathrm{LL})$ \\
\hline N. tenuis & NI17 & CBS 260.35 & + & $+(\mathrm{DL})$ \\
\hline \multirow[t]{2}{*}{ Oerskovia turbata } & N50 & $\begin{array}{l}\text { D. M. Webley, Macauley Institute, } \\
\text { Aberdeen, strain C }\end{array}$ & - & - \\
\hline & N5I & D. M. Webley, strain B & - & - \\
\hline
\end{tabular}


Table 2 (cont.)

\begin{tabular}{|c|c|c|c|c|}
\hline Name of strain & Strain no. & Source & $\begin{array}{l}\text { Arab- } \\
\text { inose }\end{array}$ & DAP \\
\hline Oerskovia turbata & $\begin{array}{l}\text { N414 } \\
\text { N415 } \\
\text { N416 } \\
\text { N418 } \\
\text { N419 }\end{array}$ & $\begin{array}{l}\text { M. P. Lechevalier, Rutgers University, 89 I } \\
\text { M. P. Lechevalier, } 689 \\
\text { M. P. Lechevalier, I7-1 I } \\
\text { M. P. Lechevalier, 713-3 } \\
\text { M. P. Lechevalier, 713-4 }\end{array}$ & $\begin{array}{l}- \\
- \\
- \\
-\end{array}$ & $\begin{array}{l}- \\
- \\
- \\
-\end{array}$ \\
\hline Streptomyces griseus & N87 & S. T. Williams, A24 & - & $+(\mathrm{LL})$ \\
\hline S. netropsis & N227 & S. T. Williams, A2 I & - & $+(L L)$ \\
\hline S. somaliensis & $\mathrm{N} 20$ & NCIB 3236 & - & $+(\mathrm{LL})$ \\
\hline S. viridochromogenes & $\mathrm{N} 226$ & S. T. Williams, A29 & - & $+(\mathrm{LL})$ \\
\hline
\end{tabular}

NRRL $=$ Northern Utilization Research and Development Division, U.S. Department of Agriculture, Peoria, Illinois, U.S.A.

\section{DISCUSSION}

All the strains found, on phenetic evidence, to belong to the genus Nocardia (Goodfellow, 1971) contained lipid LCN-A, arabinose and meso-diaminopimelic acid. Actinomadura and oerskovia strains did not possess lipid LCN-A or arabinose though cells of the former contained meso-diaminopimelic acid and a few a trace of arabinose. Certain actinomadura strains showed traces of L-diaminopimelic acid which suggested a possible link between the genera Actinomadura and Streptomyces. The chemotaxonomic characters, particularly the method to detect lipid LCN-A, allow nocardias to be reliably differentiated from actinomadura and oerskovia strains.

It is common knowledge that it is sometimes difficult to distinguish between nocardia and streptomyces strains. Streptomycetes which have lost the ability to produce aerial hyphae are not easy to separate from nocardias; similarly, freely sporulating strains of Nocardia asteroides cannot readily be differentiated, on morphological grounds, from streptomycetes. Strains can now be referred to one or other of these genera depending upon whether or not they contain lipid LCN-A and the isomer of diaminopimelic acid that they possess.

Another difficult borderline is that between the genera Nocardia and Mycobacterium. All the strains in these taxa have a wall Type IV in common, and fast growing mycobacteria cannot always be separated from nocardias by morphological and biochemical criteria. Mycobacteria, however, contain mycolic acids sensu stricto and nocardias nocardomycolic acids (Asselineau, 1966). The detection of differences in the structure of these mycolic acids involves the use of techniques such as mass spectrometry (Etémadi, $1967 b$ ) and pyrolysis gas chromatography (Lechevalier et al. 1971). These techniques are not difficult, but do require the use of equipment still lamentably beyond the resources of many diagnostic laboratories. The fact that mycobacteria do not contain lipid LCN-A is, therefore, especially relevant because the method to detect this lipid provides a simple and useful diagnostic test for differentiating nocardias from mycobacteria.

'Mycobacterium' rhodochrous has for a long time been a taxonomic enigma and even after the thorough study by Gordon (1966) its genetic location is open to question. The preliminary work of Lanéelle et al. (1965) was confirmed when Lechevalier et al. (197I) detected nocardomycolic acids in ' $M$.' rhodochrous strains and on this evidence temporarily endorsed their inclusion in the genus Nocardia. The detection of lipid LCN-A in 'M.' rhodochrous strains is further evidence of a close taxonomic affinity with nocardias. Numerical taxonomic data, however, have shown that strains of ' $M$.' rhodochrous form a taxon which is quite distinct from clusters containing nocardias (Goodfellow, 1971) but even more sharply 
separated from a cluster containing rapidly growing mycobacteria (Goodfellow, Fleming \& Sackin, 1971). It might, therefore, be important that in certain ' $M$.' rhodochrous strains the LCN-A spot had a slightly lower $R_{F}$ value than that of the reference lipid LCN-A 'asteroides' type. A further analogue with an even lower $R_{F}$ value has been found in strains of corynebacteria (Mordarska \& Mordarski, 1970). Further work, on additional corynebacteria and ' $M$.' rhodochrous strains, is needed to try to differentiate between the analogues and lipid LCN-A. The best differentiation, to date, has been obtained by Mordarska \& Mordarski (1970) by threefold chromatography in the solvent system $n$-hexane-diethyl ether-glacial acetic acid $(70: 30: 1)$. The results of the lipid and phenetic studies make us reluctant, at present, to assign strains in the ' $M$.' rhodochrous complex to the genus Nocardia.

An understanding of the chemical nature of the LCN-A spots should offer new leads for the separation of lipid LCN-A and its analogues. Although preliminary data (Mordarska \& Réthy, 1970) have shown that the LCN-A spot is heterogeneous, the main components have not yet been analysed critically. We are, therefore, not yet able to say how nearly the LCN-A spots resemble the mycolic acids found by Lechevalier et al. (1971).

Twenty strains received bearing the epithet Nocardia did not contain lipid LCN-A and gave different responses in the other chemical analyses. On the basis of these chemotaxonomic data most of these strains can be provisionally assigned to the genera Actinomadura and Streptomyces. Some of these strains may represent transitional forms between established taxa. Nocardia rangoonensis and $N$. piedadensis were considered to be streptomycetes, but in contrast to typical streptomycetes, though like nocardias, they are unable to hydrolyse starch (Modarska, Wieczorek \& Jaworska, 1970). Nocardia farcinica strain N34, NCTC 4524, did not contain lipid LCN-A and should not be retained in the genus Nocardia. This strain is allegedly a duplicate of the type strain ATCC 33I8. Our results, therefore, lend support to the proposals of Lechevalier et al. ( $197 \mathrm{I}$ ) that $N$. farcinica be considered a nomen dubium.

The nocardioform bacteria remain a formidable group. It is likely that the discovery of additional chemotaxonomic characters, particularly involving lipids, will have an important role to play in the taxonomy of these organisms.

One of us, M. G., thanks The Wellcome Trust for a Travel Grant which supported a trip to Wroclaw. This work was also supported by Medical Research Council Grant G 970/ I 2 /B. Finally, the help given, so willingly, by Grace Hedley and Barbara Lanteck has not been forgotten.

\section{REFERENCES}

Asselineau, J. (1966). The Bacterial Lipids. Paris: Hermann.

Becker, B., Lechevalier, M. P., Gordon, R. E. \& Lechevalier, H. A. (1964). Rapid differentiation between Nocardia and Streptomyces by paper chromatography of whole-cell hydrolysates. Applied Microbiology I2, $42 \mathrm{I}-423$.

Becker, B., Lechevalier, M. P. \& Lechevalier, H. A. (1965). Chemical composition of cell-wall preparations from strains of various form-genera of aerobic actinomycetes. Applied Microbiology $\mathbf{1 3}, 236$ 243.

ETÉMADI, A. H. (1967a). Structural and biogenetic correlations in mycolic acids in relation to the phylogenesis of Actinomycetales genera. Bulletin de la Société de chimie biologique 49, 695-706.

ETÉMADI, A. H. (1967b). The use of pyrolysis gas chromatography and mass spectroscopy in the study of the structure of mycolic acids. Journal of Gas Chromatography 5, 447-456.

Goodfellow, M. (197I). Numerical taxonomy of some nocardioform bacteria. Journal of General Microbiology 69, 33-80.

Goodfellow, M., Fleming, A. \& SaCkin, M. J. (197I). Differentiation of Mycobacterium rhodochrous and Runyon's Group IV mycobacteria using numerical taxonomic techniques. Journal of General Microbio$\log y$, viii. 
GoRdon, R. E. (1966). Some strains in search of a genus - Corynebacterium, Mycobacterium, Nocardia or what? Journal of General Microbiology 43, 329-343.

lanéelle, M. A., Asselineau, J. \& Castelnuovo, G. (I965). Études sur les mycobactéries et les nocardiae. IV. Composition des lipides de Mycobacterium rhodochrous, $M$. pellegrino sp., et de quelques souches de nocardiae. Annales de l'Institut Pasteur ro8, 69-82.

Lechevalier, M. P. \& LeChevalieR, H. A. (I970a). Chemical composition as a criterion in the classification of aerobic actinomycetes. International Journal of Systematic Bacteriology 20, 435-444.

Lechevalier, H. A. \& Lechevalier, M. P. (I970 $b$ ). A critical evaluation of the genera of aerobic actinomycetes. In The Actinomycetales, pp. 393-405. Edited by H. Prauser. Jena: Gustav Fischer.

Lechevalier, M. P., Horan, A. C. \& LecheValier, H. A. (1971). Lipid composition in the classification of nocardiae and mycobacteria. Journal of Bacteriology 105, 3I3-318.

MordarsKa, H. (1968). A trial of using lipids for the classification of actinomycetes. Archivum immunologiae et therapiae experimentalis $\mathrm{16}, 45-50$.

Mordarska, H. \& Mordarski, M. (I969). Comparative studies on the occurrence of lipid A, diaminopimelic acid and arabinose in Nocardia cells. Archivum immunologiae et therapiae experimentalis 17, 739-743.

Mordarska, H. \& Mordarski, M. (1970). Cell lipids of Nocardia. In The Actinomycetales, pp. 47-53. Edited by H. Prauser. Jena: Gustav Fischer.

Mordarska, H. \& Réthy, A. (1970). Preliminary studies on the chemical character of the lipid fraction in Nocardia. Archivum immunologiae et therapiae experimentalis $\mathbf{1 8}, 455-459$.

Mordarski, M., WieczoreK, J. \& JAWORSKA, B. (1970). On the conditions of amylase production by actinomycetes. Archivum immunologiae et therapiae experimentalis $18,375-381$.

Murray, I. G. \& Proctor, A. G. J. (I965). Paper chromatography as an aid to the identification of Nocardia species. Journal of General Microbiology 4r, 163-167.

Prauser, H. (1967). Contributions to the taxonomy of the Actinomycetales. Publication of the Faculty of Sciences, J. E. Purkyné University, Brno K 40, 196-199.

Prauser, H. \& Falta, R. (I968). Phagensensibilität, Zellwand-Zusammensetzung und Taxonomie von Actinomyceten. Zeitschrift fiir allgemeine Mikrobiologie 8, 39-46.

Prauser, H., Lechevalier, M. P. \& Lechevalier, H. A. (1970). Description of Oerskovia gen. n. to harbor Ørskov's motile Nocardia. Applied Microbiology r9, 534.

Sneath, P. H. A. \& Skerman, V. B. D. (1966). A list of type and reference strains of bacteria. International Journal of Systematic Bacteriology 16, I-I33.

Suput, J., Lechevalier, M. P. \& Lechevalier, H. A. (1967). Chemical composition of variants of aerobic actinomycetes. Applied Microbiology 15, 1356-1361.

Waksman, S. A. (1957). In Bergey's Manual of Determinative Bacteriology, 7 th edn. Baltimore: Williams \& Wilkins. 